\title{
'Darkness is my closest friend' (Ps 88:18b): Reflections on the saddest psalm in the Psalter
}

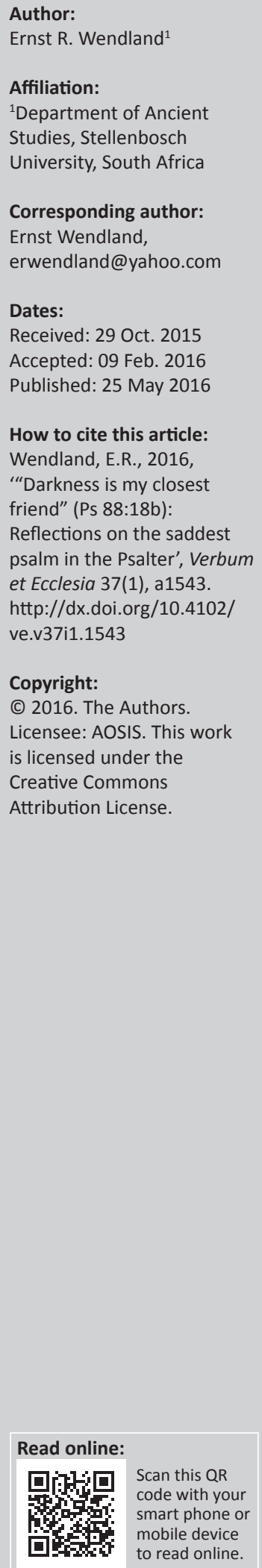

On the face of it, there are no bright spots in Psalm 88 - no hope at all for the bitterly lamenting psalmist, or seemingly for his readers today either. This intensely individual complaint expresses 'the dark night of the soul ... a state of intense spiritual anguish in which the struggling, despairing believer feels he is abandoned by God' (Boice 1996:715-716). So why has this disorienting 'psalm of disorientation' (Brueggemann \& Bellinger 2014:7) been included in the Psalter, the penultimate prayer of Book III, and what are we to make of it? One cannot of course provide definitive answers, but several suggestions may be offered based on the opinions of a number of capable Psalms scholars, coupled with some personal observations. After citing the text in Hebrew, along with my own English translation, the poetic structure of the psalm is overviewed and then selected features of its artistry and rhetoric are discussed. This study concludes with an assortment of reflections that speak to the theological importance of this dark psalm and its relevance for all those in particular who wake up in the morning, consider their current situation in life, and wonder: 'Can it get any worse?'

Intradisciplinary and/or interdisciplinary implications: This study illustrates how a close literary-structural analysis can serve to reveal insights of exegetical and theological significance while at the same time critiquing certain received scholarly positions. In particular, it challenges the prevailing opinion of commentators that Psalm 88 is entirely pessimistic in its outlook on God and life.

\section{Introduction}

Perhaps the best way to approach this unique psalm ${ }^{1}$ is simply to read it through first in order to get a general topical and emotional orientation. The Hebrew text, minus the heading (v. 1), ${ }^{2}$ is displayed in paralleled poetic lines below and numbered according to the accompanying relatively literal English translation. Putative strophic and stanza breaks are also indicated by interposed spaces and structural designations. Selected phonological features of note in Hebrew will be discussed later. A number of significant text-critical issues confront the Hebrew analyst, but due to space restrictions, only the most important of these will be considered (in footnotes), along with selected translational comments:

I-A

1. O Yahweh, God of my salvation, by day I cry out - in the night (I am) before you. ${ }^{3}$

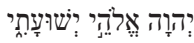

2. May my prayer come into your presence,

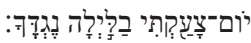
turn your ear toward my loud crying. ${ }^{4}$

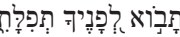

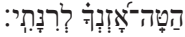

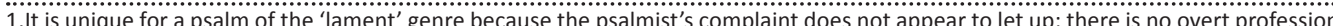
of trust that God will come to his aid (but see discussion below), nor is there any expressed hope of a future resolution to his adverse circumstances with an associated word of praise. For several other distinctive features of Psalm 88, see Mays (1994:282); Pyles (2012:21).

2.Psalm 88 begins with one of the longest titles, or superscriptions, in the Psalter - perhaps suggesting 'the importance of this extraordinary psalm to the community' (Goldingay 2007:645). This heading begins with terms similar to that of Psalm 87: 'A song (שיר),

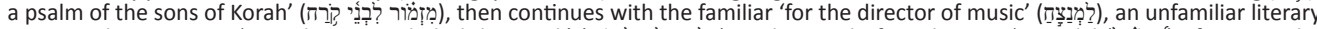

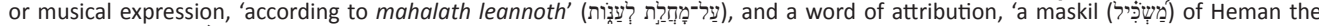
Ezrahite' (להימן האזרחי). For further discussion of the unknown terms and 'Heman the Ezrahite', (see Pyles 2012:15; Tate 1990:394-395; Terrien 2003:627).

3.Lit. 'day-I cry out, in the night before you'; versions and commentators differ as to whether this verse is divided into one or two lines. I have sided with the minority: 'the colon divides into two parallel halves, with the verb and the prepositional expression applying to both, and the expression "day" and "night" divided between them: i.e., "By day I have cried out [before you], by night [/ have cried out] before you"' (Goldingay 2007:646; cf. NIV: 'Day and night I cry out before you'). Tate (1990:393) and Tanner (2014:668-669) prefer to read v. 1 as three lines (cf. NET).

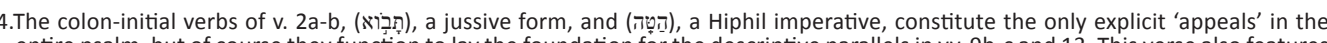
entire psalm, but of course they function to lay the foundation for the descriptive parallels in vv. $9 \mathrm{~b}-\mathrm{c}$ and 13 . This verse also features a subject - object alternation: "'my prayer" is the grammatical subject in one line and the object in the parallel line' (Berlin 1985:128-129). 
I-B

3. For my whole being is filled with troubles, and my life has reached Sheol. ${ }^{5}$

4. I am reckoned among those who are descending into the $\mathrm{Pit}^{6}$; I am like a strong man who has run out of strength.?

5. Among the dead I am released, ${ }^{8}$

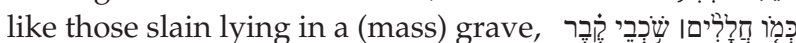
those whom you remember no more, ${ }^{9}$ yes, the ones who have been cut off from your (protective) hand.

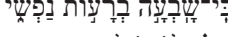

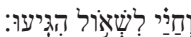

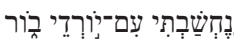

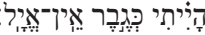

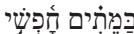

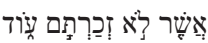

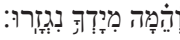

\section{II-A}

6. You have put me into the depths of the Pit

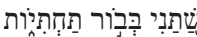

into the darkest places, those most deep. ${ }^{10}$

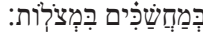

7. Your wrath has pressed down

upon me;

with all your waves you have

afflicted (me). ${ }^{11}$

SELAH

8. You have caused my associates to

shun me;

you have made me repulsive to them;

I am trapped and cannot escape ${ }^{12}$;

9a. My eyes grow weak from my affliction! ${ }^{13}$

\section{II-B}

9bc. Yahweh, I have called upon you

every day;

I spread out to you my palms (in prayer). ${ }^{14}$

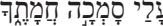

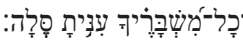

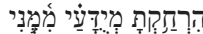

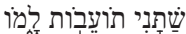

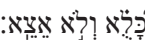

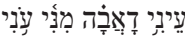

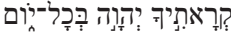

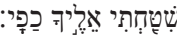

10. Do you work wonders for the dead?

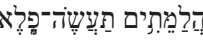
Or do dead spirits rise up to praise you ${ }^{15}$

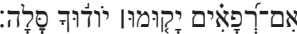
SELAH

11. Is your loyal love proclaimed in the grave?

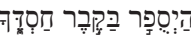
(How about) your faithfulness in the realm of Destruction? ${ }^{16}$

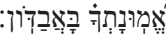

12. Are your wonders known in the

darkness?

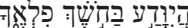

(How about) your righteousness in

the land of forgottenness?

\section{III-A}

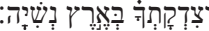

13. But I - unto you, Yahweh, I have cried for help; and in the morning my prayer confronts you. ${ }^{17}$

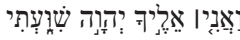

5.A chiastic structure suggests the comprehensiveness of the psalmist's calamity: $3 a$ Verb - Adjunct - Subject; 3b, Subject - Adjunct-Verb. Sheol is the place where dead people are, a nonphysical equivalent to the grave or tomb. It is not a place of punishment, unless poople are taken there before their time punishment, un ass people are taken there before their time because of wrongdoing w, but just a place where people exist - as bocied do in their graves God for there (88:3-12 [4-13])' (Goldingay 2007:705. cf. Mays 1994:282).

6.The noun, bor, ('pit, cistern') is sometimes used metonymically to refer to the grave and/or the realm of the dead, here, in obvious parallel with 'Sheol' (a poetic pair).

7. אילי is a hapax, perhaps an Aramaic loanword, found only here in the MT; it 'probably means strength' (Tate 1990:396).

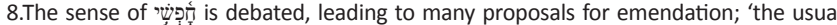
meaning...is "free"' (Tate 1990:396). The term may be used ironically here, i.e. the psalmist imagines himself to be 'free' from the troubles of earthly 'life' (v. 3b), which on the other hand, he is pleading for the Lord to save (vv. 1-2). In contrast Alter prefers 'cast away': 'a negative sense is surely required here ... imprisonment' (2007:309).

9.'The asher is expressed and thus has some emphasis' (Goldingay 2007:642) - as in the case of the subsequent, also initial 'and-they' (in in the following line.

10. מכחש is perhaps a plural of intensification. "The "deep places" (or "bottom")

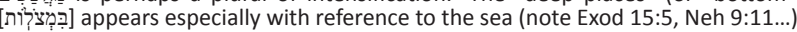
(Tate 1990:396), which fits the imagery of $7 b$.

11.Tanner prefers the ironic meaning 'you answer (me)' for the homonymous verb

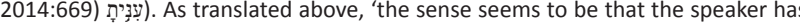
been crushed beneath the "waves" of God' (Tate 1990:397).

12.This reading is supported in Bratcher and Reyburn 1991.

13.'Constant weeping has affected his eyesight' (Harman 2011:652); however, the reference may not be physical but rather 'as a measurement of vitality' (Tanner 2014:672). The inclusion of $v 9 a$ with the preceding strophe is supported by Goldingay (2007:643) and some translations, e.g. NIV (see below)

14.'Spreading out the hands [here, lit. "palms"] toward God was a prayer gesture (see Ex 9:29, Ex 9:33; 1Ki 8:22, 1Ki 8:38; 2Ch 6:12-13, 2Ch 6:29; Ezr 9:15; Job 11:13; Is $1: 15)^{\prime}$ (NET note)

\section{III-B}

16. Your wrath has passed over upon me; your dreadful (attacks) have destroyed me.

17. They swirl around me like water all day; they close in upon me from all sides.

18. You have caused lover and companion to shun me; my closest friends - (now) darkness! ${ }^{21}$
14. Why, Yahweh, do you reject me personally? ${ }^{18}$ (Why) do you hide your face from me?

15. I have been afflicted and near death ${ }^{19}$ from my youth; I have borne your terrors; I am exhausted!20

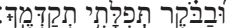

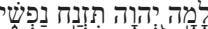

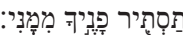

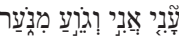

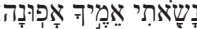

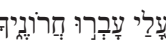

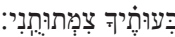

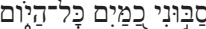

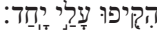

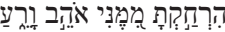

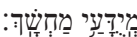

15'The Rephaim ['ר '] are related to the dead spirits in $v$. 10a and as noted in several studies in Ugaritic, maybe royal or heroic dead ones' - 'ghosts' in fact! (Tanner 2014:670; cf. Tate 1990:397).

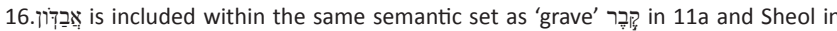
v. $3 \mathrm{~b}$ (cf. Pr 15:11).

17.For the meaning of 'confront', see Psalm 17:13; 'Since God is the problem in this psalm, it is reasonable to assume that the prayer is confronting God' (Tanne 2014:670) - in judicial, Job-like fashion, as it were (cf. Job 9). The yiqtol (noncompletive) verb significantly suggests ongoing action. This verse features a semantic-syntactic reversal, 'involving the transformation of the verbal phrase "I cry" into the nominal "my prayer"' (Berlin 1985:129).

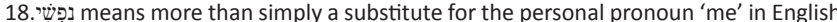
and other languages.

19.'MT's [גוֹג has the meaning of "dying" or "near to death/about to die"' (Tate 1990:398)

20.'The meaning of the Hebrew form ('afunah), which occurs only here in the OT, is unclear. It may be an adverb meaning "very much" (BDB 67 s.v.), though some prefer to emend the text to ... 'afugah ("I am numb") from the verb ... pug (see Ps 38:8; Ps 77:2)' (NET note; cf. 'I despair of life', Tate 1990:398; 'I am petrified', Tanne 2014:670; 'I am helpless', Bratcher \& Reyburn 1991)

21.'The last line in Hebrew is "my acquaintances darkness," which TEV ... and others understand to mean "and darkness is my only companion"' (Bratcher \& Reyburn 1991; cf. Tate 1990:398; see Ps 74:20). 'This line is difficult, as various translation indicate. One probable reason for the syntax is so the psalm can end with the word

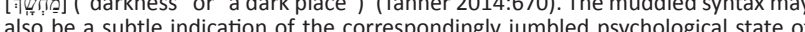
lho be a subtle indicat state of the psalmist. Instead of close friends and companions, the psalmist has only smothering "waters surrounding him - perhaps a metaphoric reference also to sake of intelligibility. This abrupt statement, just two words in the Hebrew, closes the poem on the theme of darkness that has dominated it throughout (Alter 2007:310). [7in] ("darkness" or "a dark place")' (Tanner 2014:670). The muddled syntax may 


\section{Structural features}

The following chart summarises the major and minor structural divisions of Psalm 88 along with a functional ('speech-act') description of the poetic units (Box 1).

The distressed semantic surface of Psalm 88 disguises an underlying symmetrical topical and functional structure. Three 'stanzas' (major poetic units) are posited, each of which includes 2-3 'strophes' (minor units; poetic 'paragraphs'). ${ }^{22}$ The psalm divides into two halves of 20 lines each, with the initial and longest stanza I being balanced by stanzas II-III. Each stanza begins with a plaintive 'appeal', or 'calling out' to Yahweh (marked by a vocative) for help (vv. 1a, 9b, 13a). ${ }^{23}$ The second and third strophes of stanza I consist of eight lines each, with the last verse of each strophe ending in a tetracolon. Strophe B (vv. 3-5) expresses a 'descriptive lament', with a predominance of first-person subject pronouns as the psalmist figuratively portrays his present plight. In strophe C (vv. 6-9a), second-person verbs take over as the lament turns more to an 'accusation' suggesting that Yahweh is persecuting the psalmist. ${ }^{24}$

In the psalm's second half, both stanzas manifest a similar two-part structure, but what follows the short initial 'appeal' differs significantly in each case. In strophe III-B we hear another 'accusatory lament' (vv. 14-18) which closely parallels that of I-C, except that it is intensified by length (10 vs. 8 lines), by more desperate imagery (see below), and by an initial critical rhetorical question: 'Why, O LORD...'

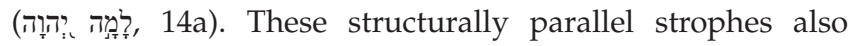
conclude with similar allegations: 'You have taken from me my closest friends' (8a, NIV) - 'You have taken my companions and loved ones from me' (18a, NIV). ${ }^{25}$

What is thematically and structurally distinctive in Psalm 88 is the series of six rhetorical questions that comprise the second strophe of stanza two (II-B). ${ }^{26}$ Each one of the mock queries anticipates a negative response, e.g. 'Do you show your wonders to the dead?' (10a). However, these interrogations seem to have more significance than usually interpreted, that is, as being merely additional accusations against the injustice of God. Rather, this highly emotive sequence may be construed as lending prolonged 'rhetorical support' to the psalmist's implicit faith (expressed already in v. 1), thus underscoring his passionate pleas as he overtly

22.After completing my analysis, I discovered the study of Pyles, who proposes a similar macrostructure for Psalm 88 (2012:15); see also Gerstenberger's formsimilar macrostructure for Psalm 88 (2012:15); see
critical outline (2001:141) and Terrien 2003:624-626.

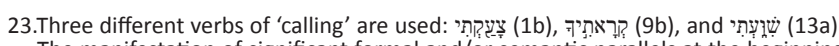
The manifestation of significant formal and/or semantic parallels at the beginning of distinct poetic units is a discourse demarcative device termed 'anaphora', which is part of the collective technique delineating a structural 'aperture' (Wendland 2004:127).

24.There are subtle pronominal shifts at the end of each strophe: remember them' in v. 5c anticipates the 'you' sequence of verbs in strophe I-C; 'I go out' in v. 8c prepares for 'I call' in the plea of v. $9 \mathrm{~b}$.

25.Note the intensification that is apparent in the second of these cola, in a manner that reflects what is typical in the Hebrew A-B parallelism of adjacent poetic lines (similarly strophe III-B in relation to I-C). Robert Alter has a good explanation of this common poetic feature in relation to vv. 12-13 (Alter 1985:14).

26.In his classic study, Watson also calls attention to this (Watson 1984:339).
BOX 1: Strophes and Rhetorical Functions of Psalm 88.

\begin{tabular}{|lccl|}
\hline Unit & Verses & Lines & Rhetorical function \\
I-A & $1-2$ & 4 & Initial Appeal to YHWH \\
I-B & $3-5$ & 8 & Descriptive Lament \\
I-C & $6-9 a$ & 8 & Accusatory Lament \\
II-A & $9 b-C$ & 2 & Appeal to YHWH \\
II-B & $10-12$ & 6 & Rhetorical support (Profession) \\
III-A & 13 & 2 & Appeal to YHWH \\
III-B & $14-18$ & 10 & Accusatory Lament \\
\hline
\end{tabular}

Note: The use of boldface and italics highlights rhetorical parallels within the structure of Psalm 88, while the underlined expression indicates the psalm's prominent rhetorical and thematic central core.

gesticulates with his hands towards the heavens in heartfelt prayer (9c). 'All of the questions have the same point - Yes, $\mathrm{YHWH}$ is God of the living, and if YHWH wants to be taken seriously, then YHWH must keep the speaker among the living ...' (Brueggemann \& Bellinger 2014:380). In this, 'the bleakest of all the psalms', at the very least there remains this 'glimmer of light that the psalmist can still pray - he is still able to appeal to Yahweh' (Johnston 2005:79).

But why should God answer him? It is simply, but significantly, because if God would allow the psalmist to pass down into Sheol and die (vv. 3-4), then the latter's potential paean of praise (iti', 10b) for Yahweh's manifestations of

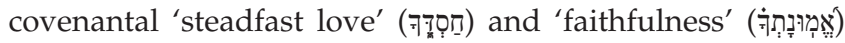

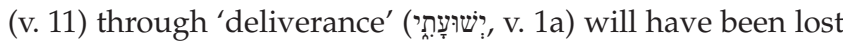
to the world and silenced within the community of the faithful ('Zion' of Ps 87; cf. Ps 89:1-2, where these same two divine attributes are lauded by the psalmist, twice in fact). ${ }^{27}$ So what we arguably have here in strophe II-B are implied professions of trust on the part of the psalmist - that despite his precarious, near-death situation and his forceful protestations against God for allowing, even causing, this to happen, he nevertheless retains a foundational faith that it is not utterly too late for the Lord to resolve things by making his 'wondrous works' manifest (vv. 10a, 12a), this time on behalf of his benighted, bemused plaintiff (v. 18b).

What difference does an accurate discourse structure make? Obviously, it helps the specialist and lay-person alike to grasp the larger thematic organisation of a psalm, for example, and how the psalmist has arranged his prayer in order to make the greatest impression, from a human appellant's point of view. As we see in the case of Psalm 88, the larger structure clearly reveals the threefold division into stanzas, each leading off with an appeal to the Lord for help and with the first and last stanzas ending in parallel with an accusatory lament (I-C, III-B). The second part of the middle stanza is conspicuously different by way of contrast, thus making it stand out for the observant reader (listener), being vocally marked by means of the dramatic series of rhetorical questions, which one might view as the psalm's emotive and thematic peak.

However, there is by no means complete scholarly consensus regarding this psalm's larger structural organisation. Tanner,

27. These two covenant-centered thematic qualities are paired twice more in Psalm 89 , in vv. 33 and 49. 
for example, does not recognise verses $9 \mathrm{~b}-\mathrm{c}$ and 13 as parallel 'appeals' that essentially reiterate the prayer's aperture (vv. 1-2). She further suggests that 'vv. 1-2 and 9 provide an inclusio around this large section which suggests that [it] should not be separated into plea and complaint as individual sections' (Tanner 2014:668). This proposal differs considerably from the structure outlined above, so readers will have to study the text and come to their own conclusion on the matter. My contention is that the concept of 'inclusio' (marking the beginning and ending of some unit) is overused in such compositional analyses and must be clearly distinguished from at least two other macro-demarcative devices in Hebrew poetry, namely, 'anaphora' (distinct unit beginnings) and 'epiphora' (distinct unit endings) (Wendland 2004:123-130).

These structural issues are not of interest and importance only to scholars, but they have invariably been 'translated' into the published formats of the various versions that all believers access on a regular basis, whether during public worship or in private devotions. So what are people to make of the diversity that confronts them in their Bibles? For example, the following popular English translations indicate internal breaks in the printed text by means of a line space before the verses indicated in the listing below (my segmentation is given last for comparison):

$\begin{array}{ll}\text { English Standard Version } & 8-\mathbf{1 3} \\ \text { New International Version } & 3-6-9 b-\mathbf{1 3} \\ \text { New Revised Standard Version } & 3-8-\mathbf{1 3} \\ \text { Revised English Bible } & 10-\mathbf{1 3} \\ \text { New American Bible } & 9 b-\mathbf{1 3} \\ \text { New Jerusalem Bible } & 3-6-8-10-\mathbf{1 3}-15-17 \\ \text { New Living Bible } & 8-15 \\ \text { Wendland } & 3-6-9 b-10-\mathbf{1 3}-14\end{array}$

So should the attentive reader conclude that these divisions do not really make all that much difference - to each his own, as it were? On the contrary, such partitions will naturally affect one's mental and oral reading of the psalm, for example, in making brief pauses where such breaks occur in the text, and through onset or ending intonational patterns (in English). Certain pause-points are well established in these versions, such as the one occurring before v. 13. Others are suspect, like the New Living Bible's breaks at both selahs $(8,15)$, which do not correspond with a justifiable structural shift. These differences in formatting the text on the printed page further illustrate the literary principle that 'form has meaning', especially where poetry is concerned.

\section{Rhetorical features}

The 'rhetoric' of a literary text is concerned with its 'persuasiveness' - with how the author has utilised various artistic and rhetorical features to support the text's structural contours, to highlight its main theme and subpoints, and to create global as well as local points of impact and appeal within the composition (Wendland 2004:ch.6). Considering Psalm 88 as a whole, we notice how the subject of illness, death, and the grave has been foregrounded throughout by varied images, figurative terms, and associated references that are familiar to most students of the Hebrew Bible (following the NET translation). Indeed, the darkness of 'death is so near and so real that it becomes the subject of the lament' (Mays 1994:282):

Sheol (3) - grave (4) - the dead (5) - corpses lying in the grave (5) whom you remember no more (5) - cut off (5) - the lowest regions of the pit (6) - in the dark places (6) - in the watery depths (6) - overwhelm...with all your waves (7) - me, an appalling sight (8) - I am trapped (8) - the dead (10) - the departed spirits (10) - the grave (11) - the place of the dead (11) the dark region (12) - the land of oblivion (12) - on the verge of death (15) - numb with pain (15) - your terrors destroy me (16) they surround me like water (17) - leave me alone in the darkness (18).

These melancholy words and phrases act as a cohesive backbone running from beginning to end that allows the psalmist both to express his deeply-felt emotions and also to fervently empower his petitions to a God who is hearing, but presently not overtly responding to his appeals (vv. 1-2,14).

Therefore, one might argue that the author's emotive state is not simply a continuous slide in this psalm, moving progressively downwards towards the 'deep darkness'

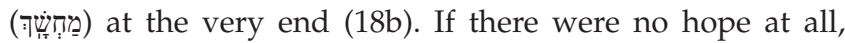
why would he persevere in praying to the Lord for help, as reiterated prominently at the head of each stanza (vv. 1-2, 9, 13)? Indeed, as noted, why begin by addressing Yahweh as 'the

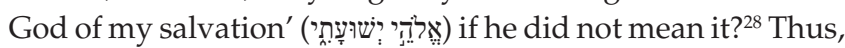
the notion of a 'God (who is able to) save me' acts as a thematic frame of reference that guides one's subsequent interpretation throughout the entire text. Furthermore, as suggested above, we encounter that prominent string of rhetorical questions right in the middle of the prayer (stanza II, vv. 10-12), which I construe as the psalmist's residual argument of resistance - his bold verbal effort to swim out in faith against the stream, as it were, of the rushing waters of adversity that are flowing all around him (vv. 7, 17). ${ }^{29}$ In literary structural terms then, what we have is a common $\mathrm{A}-\mathrm{B}-\mathrm{A}^{\prime}$ 'ring' tectonic arrangement in which stanza III $\left(\mathrm{A}^{\prime}\right)$ reiterates the basic complaint of stanza I (A), but with renewed rhetorical vigour that pleads the psalmist's desperate plight before the Lord. The real message of the prayer, however, lies in the middle in stanza II (B), where the psalmist's enduring trust in Yahweh's covenantal attributes

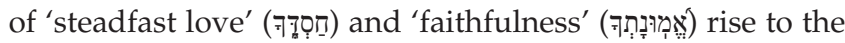
occasion (v. 11) and reflect a ray of hope that God will yet

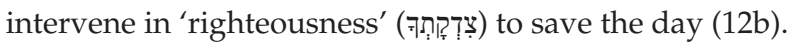

28. Of course, one could interpret this initial appellation as purely ironic, even sarcastic, in tone, a hermeneutical perspective that would then apply elsewhere in the psalm, stanza II in particular (e.g. Tanner 2014:671; Terrien 2003:628).

29.This series of six rhetorical questions constitutes a prominent 'communicative clue' within the text, which is 'aimed at guiding the audience to the correct interpretation of the utterance' (Hatim 2014:111), or in this case, the entire central section of Psalm 88. Communicative clues are 'grammatical and lexical features which Psalm 88. Communicative clues are 'grammatical and lexical features which indicate the purposes for which utterances are used (e.g. the use of paralle structures or alliteration to convey irony)' (Hatim 2014:283). When compounded at a particular place in the discourse, as in this case, they alert readers and hearers like to the fact that something significant is being said in the text at that point, an they must therefore take note and ask why. Bible translators, for their part, must endeavor to render such features with functional equivalence in their language (Wendland 2004:ch. 7). 
In the remainder of this section I will overview a number of the other rhetorical features to be found in Psalm 88 that function to highlight as well as to reinforce selected aspects of the psalmist's lament to the Lord. This listing summarises the most significant phonological and morphological devices that serve to distinguish the dramatic rhythmic Hebrew soundscape of Psalm 88:

- The number of 'lexical units' (or 'accent groups') per poetic line ('colon') remains fairly constant throughout the psalm, averaging the normal three; however, the lines do lengthen somewhat in the final stanza (III),,$^{30}$ perhaps reflecting the especially dire imagery and deep feelings to be found in this final portion of the prayer. ${ }^{31}$

- $\quad$ The convergence of 1pers. sg. (-iy) and 2pers. m. sg. (-cha) pronouns, so prominent in the opening appeal (vv. 1-2), continues unabated throughout the psalm. This strong interpersonal interaction is occasionally complicated by third-person references to the psalmist's former friends and loved ones (vv. 8, 18), now alienated as a result of the Lord's afflictions levied upon him (as in the case of Job, e.g. 19:13-22).

- The 'deep dark'-like confusion experienced in the 'depths' of the 'pit' of death might be intimated by the juxtaposition of masculine and feminine plural nouns (v. 6b), each of which begins with similar sounds:

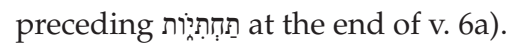

- The personalised content and feeling of lines $8 \mathrm{~b}$ and $8 \mathrm{c}$

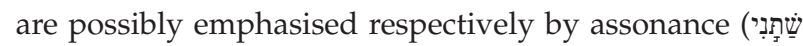

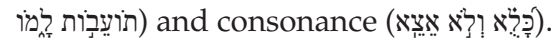

- The 'affliction' being felt in the psalmist's 'eyes' (metonymic for the whole 'self') may be underscored by the close correspondence in the sounds of these lexical

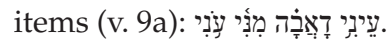

- Each of the initial lines of the paired rhetorical questions in vv. 10-12 is marked by the interrogative prefix ( 7 ). The first query is immediately 'seconded' by the next to create a strongly rhythmic sequence that pounds the psalmist's indirect assertions home and dramatises the 'eschatological tension' (Pyles 2012:19) that is implicit in his strident pleas: 'What glory is there for you, God, in my death?!'

- A chiastic arrangement effectively highlights the covenantal qualities of Yahweh in contrast to the imagery of death in v. 11a-b: This effect is

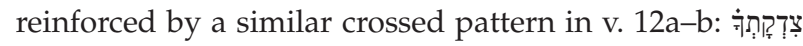

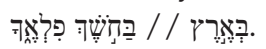

- Front-shifted pronominal forms patently juxtapose the

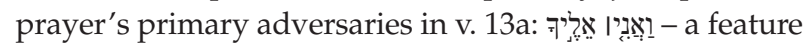

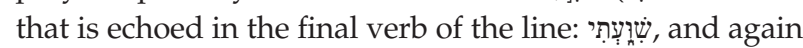

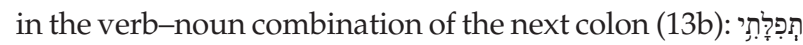

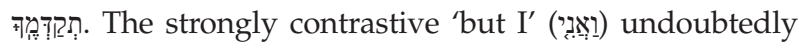

30.This observation is supported by Tate's analysis (Tate 1990:393-394), which is based on Craigie's understanding of Hebrew poetic lineal 'rhythm': 'Any approach to Hebrew meter is essentially descriptive of the phenomena of line length or relative line lengths, there being no evidence that a theory or system of meter was ever articulated in ancient Israel' (Craigie 1983:38).

31. The conventional sea imagery intensifies the psalmist's dread: 'As in other psalms, the descent into the Pit of death is imagistically equated with drowning beneath the waves of the sea' (Alter 2007:309). has reference to 'the dead' of the preceding strophe (v. 10): 'I am not there yet!' - the psalmist seems to defiantly assert.

- Initial, similar-sounding lexical items foreground the psalmist's deep feeling of 'personal affliction' in v. 15a: עָּנִי אָנִני (cf. 9a).

- Another chiastic construction stresses the completeness of Yahweh's demoralisation of the psalmist in v. 16a-b: .

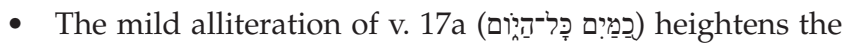
impact of the watery imagery of the 'cistern' of death that

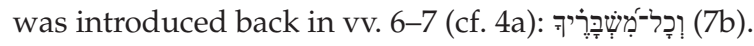

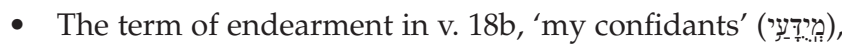

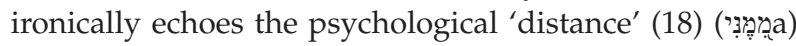
that Yahweh has set between the psalmist and those closest to him in life - a situation that only exacerbates the feeling of utter 'darkness' (מָחָשָׁ) that characterises his present circumstances.

Throughout this poetic text, then, a diverse assortment of rhetorical devices periodically punctuates the psalmist's prayer in a manner that augments the oral-aural impression of his sustained progression of pleas and laments and also directs the listener's attention to some of the crucial aspects of his passionate precatory argument with the Lord. In Psalm 88 'the rhetoric builds to match the intensity of the speaker's situation' (Brueggemann 1995:56) - growing ever darker as the discourse develops, but not to the point where his faith is totally defeated.

\section{Intertextual influence on interpretation}

As the hermeneutical approach of 'canonical criticism' has suggested, the individual psalms of the Psalter must not be interpreted in isolation, but rather in conjunction with one another - all the more so in the case of obvious smaller collections or groupings within the five 'books'. An early description of this method asserts that the move beyond form criticism [may] be made by directing attention to the final form of the Psalter in order to determine how the meaning of individual Psalms may be affected by their titles and by their placement in the canonical form of the Psalter' (McCann 1993:18). "The juxtaposition of a psalm with another portion of scripture [pre-eminently another psalm] creates a new context for a communal response which is different in kind from free association." On the other hand, the limit of 150 psalms defines parameters in the interpretive possibilities' (VanGemeren 2013:31, citing Childs 1979:523). ${ }^{32}$ It is clear that Psalm 88 belongs to a psalmic subsection within the Psalter, as designated in its heading 'of the Sons of Korah' ${ }^{33}$ Twelve psalms are ascribed to this group, situated in strategic structural positions within the Psalter: Psalm 42-49

32 .'Canonical critics... are concerned with questions about the origins and uses of individual as well as collections of psalms. ... How were collections of psalms and various individual psalms incorporated into the Psalter? When? By whom? For what reason?' (DeClaissé-Walford 2014:xi).

33. Although he recognizes that Psalm 88 belongs to the 'Sons of Korah' collection, Buss strangely 'excludes' it from his survey of this group 'since it differs from the rest of the Korah psalms in content' (Buss 1963:382). 
to begin Book II and Psalm 84-89 to conclude Book III. ${ }^{34}$ So what possible influence might the two psalms that surround Psalm 88 have on its interpretation?

The most obvious effect can be heard in the first two verses of Psalm 89 (NIV) - in dramatic contrast to the 'darkness' of isolation and death that ends Psalm 88:

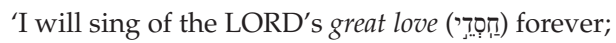

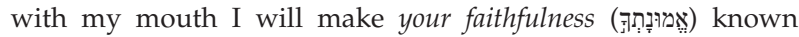
through all generations.

I will declare that your love (חיֶ:) stands firm forever;

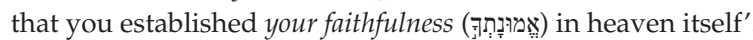

As noted earlier, the exact same covenantal correlates of 'steadfast love' and 'faithfulness' appear in the midst of Psalm 88 (v. 11). Can such close co-occurrence be a mere coincidence? In another nearby psalm attributed to the Sons of Korah, a very similar conjunction of these concepts is

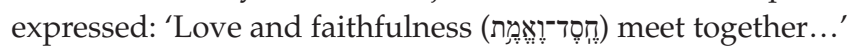
(85:10). Both Psalms 85 and 89 bemoan the Lord's punitive anger (85:4-5, 89:38), which has resulted in disastrous loss for the nation as a whole in the former case (85:6-7), for the anointed king and his dynasty in the latter $(89: 39,51)$. But each of these psalms also professes bright visions of hope and a trusting reliance on God's future intervention on behalf of his faithful people - more strongly in Psalm 85 (vv. 1-3, 8-13), but clearly audible in the majority of Psalm 89 as well (vv. 1-37). ${ }^{35}$ These intertextual correspondences are significant 'contextual clues' from a canon-critical perspective that Psalm 88 must not be understood in isolation, but rather within the reflected hermeneutical import of the psalms that surround it, including the universally optimistic 'Zion song' celebrated in Psalm 87.36

In this approach, even more distant echoes, if resonant enough semantically and contextually, should not be ignored, for example, the collective answer to the pivotal series of rhetorical questions in Psalm 88:10-12, left implicit there, but responded to most positively in the case of similar queries found in Psalm 30:8 - 'You turned my wailing into

34.Note that in many manuscripts Psalm 42-43 constitute a single psalm (Psalm 43 has no heading and has a common refrain with Psalm 42); Psalm 86 is entitled as 'prayer of David'; Psalm 89 does not include 'Sons of Korah' in the heading, but it is attributed to 'Ethan the Ezrahite', like 'Heman' of Psalm 88, so it is arguable that both belonged to this family grouping (cf. $1 \mathrm{Chr} 6: 31-47 ; 15: 4-19$ ). More speculatively with reference to the respective superscriptions, it may be suggested thet 'Sons of Korah' links Psalm 88 with the preceding Psalm 87, while 'the Ezrahite' links Psalm 88 with the following Psalm 89 (Pyles 2012:15).

35.I recognize that just as Psalm 88 is regarded as 'the darkest individual lament', so also Psalm 89 is 'the darkest complaint of the nation' because it ends with apparent also Psalm 89 is 'the darkest complaint of the nation' because it ends with apparent plea for remembrance (vv. 50-52)' (Pyles 2012:22; Wells 2012:174). On the other plea for remembrance (vv. 50-52)' (Pyles 2012:22; Wells 2012:174). On the other hand, the first 37 verses of Psalm 89 cannot be simply discounted or construed as
an ironic introduction (much too long!). Thus, the 'forever' (ע) that couples an ironic introduction (much too long!). Thus, the 'forever' (עָîn) that couple
Yahweh's 'steadfast love' (89:1-2) with his covenantal commitment to the Davidic 'royal line' (vv. 36-37, a double inclusio; cf. vv. 28-29) provides a solid foundation for renewed hope in the Lord's 'faithfulness' (vv. 1b, 2b, 5b, 8b, 14b, 33b, 37b, 49b) to fully keep all his promises, in one way or another, despite the repeated failures of his people (vv. 30-34) and their resultant punishment as a nation and in the person of their 'anointed one' (vv. 38-51).

36.This concurrence of one of the most positive and cheerful psalms with the most sorrowful song in the Psalter cannot be coincidental; it is arguably a 'communicative clue' on the macro-level of Book III at least. The communal 'communicative clue' on the macro-level of Book th at least. The communal representing a spokesman for the exiled people of 'Zion' as a whole during a representing a spokesman for the exiled people of 'Zion' as a whole during a
period of severe testing and the seeming loss of their glorious status as the 'city of God' (87:1-3). dancing...' (30:11). Similarly, the final blessed outcome to Job's period of severe crisis and sharp verbal reaction to Yahweh's apparent neglect would undoubtedly be recalled by supplicants when uttering a passage from Psalm 88 that closely parallels words in Job, for example: 'You have taken from me my closest friends and have made me repulsive to them; I am confined and cannot escape!' (v. 8) - 'He [God] has alienated my brothers from me; my acquaintances are completely estranged from me. Why is life given to a man whose way is hidden - whom God has hedged in?' (Job 19:13; 3:23)..$^{37}$ Could Psalm 88 then be another instance of where scripture is required to interpret itself? Thus, a reassuring response to Heman the Ezrahite's lament (and that of all believers in a similar position) comes not within the psalm itself (as in the case of Ps 85:8-13) but from those prayers that surround it and similar familiar texts found in their common sacred canon.

\section{Conclusion}

\section{What have we learned from this sad psalm?}

First, from a methodological perspective, we might suggest that any effort to 'dig deeper' exegetically always pays off in greater insight with regard to the sense and significance of a given passage, long or short. As part of this exploratory process, it is important to include 'literary analysis' as a component of the student's investigative toolkit; thus, any biblical text must be viewed also in the light of its rhetorical structure and linguistic (including poetic) artistry. Finally, an old principle of biblical hermeneutics normally needs to be applied as well: Scripture texts cannot be fully understood and interpreted in isolation; every text study will inevitably be enriched by an exploration of its 'co-text' (intertextual context), both adjacent and remote in terms of textual 'distance' within the canon. ${ }^{38}$

With respect then to the more substantial, theological lesson of Psalm 88, we might ask along with Derek Kidner: 'With darkness as its final word, what is the role of this psalm in Scripture' (Kidner 1973:319), and in the lives of the faithful? Kidner goes on to make a number of perceptive responses (Kidner 1973:loc cit) that can assist us as we reflect upon the practical meaning of this psalm for us today: First, there is Psalm 88 's 'witness to the possibility of unrelieved suffering as a believer's earthly lot'. In many segments of Christianity nowadays, adherents seem to think that God owes them a prosperous life, free of all suffering, pain, or loss. On the contrary, Psalm 88 reminds us that 'the happy ending of most psalms of this type is seen to be a bonus, not a due'. Second, "the psalm adds its voice to the "groaning in travail" [Rom 8:22] which forbids us to accept the present order as final'. The Lord of our salvation (v. 1), who sent his Son into

37.This separation from "the ones who know me' (v. 8) by being cast into a "pit' of death (v. 6-which could also function as a cistern for water, v. 7) might even recall the Joseph story of Genesis 37:21-24.

38.Such intertextual investigation of the Psalms would of course include the New Testament, which makes frequent overt and covert reference to the Psalter. For example, what influence might there be on our understanding of Christ's parable example, what influence might there be on our understanding of Christ's parable
of the 'unjust judge' of Luke 18 if we surmise that in v. 7 he was actually alluding to Psalm 88:1-2 (note also his conclusion in v. 8)? 
this world to experience death in dire reality on behalf of humanity (effectively replacing the psalmist of this psalm, Jn 1:5), is also a God of 'justice' (v. 12), who will see to it that the moral order is perfectly restored in the end (cf. Lk 18:1, 8). 'Thirdly, this author, like Job, does not give up - he completes his prayer, still in the dark and totally unrewarded'. Suffering in utter, uninterrupted loneliness, to whom else can he turn except to the God who alone can answer, at his appointed time, efficaciously? ${ }^{39}$ So, if there were yet another verse added to this psalm, it would undoubtedly follow the pattern and parallel the three prior stanza-initial pleas that have structured the text: 'O LORD, I cry out to you...' (vv. 1a, 9b, 13a). ${ }^{40}$ Finally, there is the intimation in the very superscription of Psalm 88, which specifically names 'Heman the Ezrahite', that the psalmist's life history did not end with that particular lament. 'His existence was no mistake; there was a divine plan bigger than he knew, and a place in it reserved most carefully for him'. Indeed, the preceding psalm would have been a constant verbal reminder of that fact: 'The LORD will write [his name] in the register of the peoples: "This one was born in Zion!"' (Ps 87:6).

Psalm 88 assures us that it is true: the Psalter does include a psalm for every season of the soul - for the black days and well as the bright (Ps 139:12). In Psalm 88 we descend about as low as we can go emotionally, ${ }^{41}$ yet our hope in a listening, personally relational Lord remains. And so, we never give up on prayer; God is always there, but he may have a good reason for playing 'hard to reach' in specific cases. He does not owe us an explanation, ${ }^{42}$ and for our part, we need not hold back with our most frank and fervent emotive expressions of distress and disappointment in how things are working out. ${ }^{43}$ Heman's lamentation provides us with a model prayer for all such occasions, when 'darkness - does seem to be our closest friend'.

39.'The reiteration of verses $1-2,9$, and 13 also attests that unanswered prayer does not lead to lack of faith, or silence, or resignation - it leads rather to more urgent, vigorous petition ...' (Brueggemann \& Bellinger 2014:381). 'The speaker is on the verge of death, but prayer is the lifeline which keeps him/her from the Pit...[s/he] keeps death away by conversation directed to God' (Tate 1990:405).

40.The implied continuity of the psalmist's 'crying' out to the Lord for help is indicated by the final 'imperfect' (non-completive) verb in v. 13b (ת) (ת): After another dark night of weeping, he will awaken to a new day, hopefully to witness God's delayed deliverance (v. 1).

41.'This prayer provides legitimacy to all the prayers of praise where the world looks perfect' (Tanner 2014:673).

42.'It is clear that the God of the Bible is no reliable antidote to evil.... Therefore the large rational issue of theodicy looms in critical reflection, but biblical interpretation must take care not to seek explanations for the unexplainable. The silence of God properly evokes not explanation but a rich blend of patient waiting silence of God properly evokes not explanation but a rich blend of patient waiting
and impatient demand' (Brueggemann \& Bellinger 2014:382) - as amply and impatient deman
evidenced in Psalm 88.

43.'The very fact that Psalm 88 is in the Bible - that it wasn't "censored" and deleted... as some sacrilegious aberration from what should be the "correct" way of relating to God - tells us that it is okay to be silent or to question God severely in our distresses' (Howard 2013:254).

\section{Acknowledgements Competing interests}

The author declares that he has no financial or personal relationships which may have inappropriately influenced him in writing this article.

\section{References}

Alter, R., 1985, The art of biblical poetry, Basic Books, New York.

Alter, R., 2007, The book of Psalms: A translation with commentary, W.W. Norton, New York.

Berlin, A., 1985, The dynamics of biblical parallelism, Indiana University Press, Bloomington, IN.

Boice, J.M, 1996, Psalms: An expositional commentary, vol. 2 (42-106), Baker Books, Grand Rapids, MI.

Bratcher, R.G. \& Reyburn, W.D., 1991, A translator's handbook on the book of Psalms, United Bible Societies, New York, NY [the ParaText electronic version was accessed].

Brueggemann, W., edited by Miller, P.D., 1995, The Psalms: The life of faith, Fortress Press, Minneapolis, MN.

Brueggemann, W. \& Bellinger, W.H., Jr., 2014, Psalms, Cambridge University Press, Cambridge, UK.

Buss, M.J. 1963, 'The Psalms of Asaph and Korah', Journal of Biblical Literature 82(4), 382-392. http://dx.doi.org/10.2307/3264694

Childs, B.S., 1979, Introduction to the Old Testament as Scripture, Fortress Press, Philadelphia, PA.

Craigie, P.C., 1983, Psalms 1 - 50 (Word Biblical Commentary), Word Books, Waco, TX.

DeClaissé-Walford, N.L., (ed.), 2014, The shape and shaping of Psalms: The current state of scholarship, SBL Press, Atlanta, GA.

Gerstenberger, E.S., 2001, Psalms, part 2, and Lamentations (The Forms of the Old Testament Literature), Eerdmans, Grand Rapids, MI.

Goldingay, J., 2007, Psalms, vol. 2, Baker Academic, Grand Rapids, MI, pp. 42-89.

Harman, A., 2011, Psalms, vol. 2, Mentor, Fearn, UK, pp. 73-150.

Hatim, B., 2014, Teaching and researching translation, 2nd edn., Pearson Education, Harlow, UK.

Howard, D.M., Jr., 2013, 'Psalm 88: Praising God in the bad times', in A.J. Schmutzer \& D.M. Howard, Jr., (eds.), The Psalms: Language for all seasons of the soul, pp. 247-254, Moody Press, Chicago, IL.

Johnston, P.S., 2005, 'The Psalms and distress', in D. Firth \& P.S. Johnston (eds.), Interpreting the Psalms: Issues and approaches, pp. 63-84, IVP Academic, Downers Grove, IL.

Kidner, D., 1973, Psalms 73-150 (Tyndale OT Commentaries), InterVarsity, Downers Grove, IL.

Mays, J.L., 1994, Psalms (Interpretation), John Knox, Knoxville, TN.

McCann, J.C., Jr., 1993, A theological introduction to the book of Psalms, Abingdon Press, Nashville, TN.

Pyles, A.R., 2012, 'Drowning in the depths of darkness: A consideration of Psalm 88 with a new translation', Canadian Theological Review 2(1), 13-28.

Tanner, B.L., 2014, 'Psalm 88: I am as one dead', in N.L. deClaissé-Walford, R.A. Jacobson \& B.L. Tanner (eds.), The book of Psalms (NICOT), pp. 668-673, Eerdmans, Grand Rapids, MI.

Tate, M.E., 1990, Psalms 51-100 (Word Biblical Commentary), Word Books, Waco, TX.

Terrien, S.L., 2003, The Psalms, strophic structure and theological commentary, Eerdmans, Grand Rapids, MI.

VanGemeren, W.A., 2013, 'Literary analysis', in A.J. Schmutzer \& D.M. Howard, Jr., (eds.), The Psalms: Language for all seasons of the soul, pp. 29-48, Moody Press, Chicago, IL.

Watson, W.G.E., 1984, Classical Hebrew poetry, JSOT Press, Sheffield.

Wells, C.R, 2012, 'The cry of the heart and the cure of the soul', in C.R. Wells \& R. Van Neste (eds.), Forgotten songs: Reclaiming the Psalms for Christian worship, pp. 167-187, Broadman \& Holman, Nashville, TN.

Wendland, E.R., 2004, Translating the literature of Scripture: A literary-rhetorical approach to Bible translation, SIL International, Dallas, TX. 